\title{
質量イメージングによる低酸素領域集積性ニトロイミダゾール薬剤の集積機序の解明
}

\author{
志水陽一
}

\section{Accumulation Mechanism of 2-Nitroimidazole-based Hypoxia Imaging Probes Revealed by Imaging Mass Spectrometry}

\author{
Yoichi Shimizu \\ Department of Radiology, Kyoto University Hospital; 54 Shogoinkawahara-cho, Sakyo-ku, Kyoto 606-8507, Japan.
}

(Received July 1, 2018)

\begin{abstract}
Hypoxia in tumor tissues plays a pivotal role in tumor progression and angiogenesis, and is associated with cancer therapeutic resistance. For the diagnosis of hypoxia, non-invasive imaging techniques, especially positron emission tomography (PET) with 2-nitroimidazole-based probes, are used, since 2-nitroimidazole-based probes are considered to undergo reductive metabolism on their 2-nitroimidazole moiety and become trapped in hypoxic cells. However, the detailed mechanism of their accumulation remains unclear because of the difficulty in estimating the metabolites by radioisotopic analysis. Imaging mass spectrometry (IMS) can distinguish the distribution patterns of the drug and its metabolites. To clarify the accumulation mechanism of 2-nitroimidazole-based probes in hypoxic cells, we evaluated $\left[{ }^{18} \mathrm{~F}\right]$ fluoromisonidazole (FMISO), a 2-nitroimidazole-based PET probe, in combination with radioisotopic analysis and IMS. We found that the glutathione conjugate of reduced FMISO (amino-FMISO-GS) was the main FMISO metabolite, and was specifically distributed in the hypoxic regions of tumors. The same phenomenon was observed when we examined another 2-nitroimidazole-based probe, pimonidazole. The in vitro cellular uptake study revealed that FMISO accumulation in hypoxic cells depends on the cell type. In those cells exhibiting higher FMISO uptake, the reactive glutathione level and enzyme (glutathione $S$-transferase; GST) activity catalyzing the glutathione conjugation reaction was significantly higher, whereas the expression level of the efflux transporter (multidrug resistance-associated protein 1; MRP1) was significantly lower. Our study suggests that 2-nitroimidazole-based probes accumulate in hypoxic cells via glutathione conjugation following reductive metabolism, which depends not only on the glutathione conjugation capacity of the cells but also on hypoxic conditions.
\end{abstract}

Key words — hypoxia; 2-nitroimidazole; imaging mass spectrometry; positron emission tomography

\section{1.はじめに}

固形腫瘍内において，がん細胞の増殖立進による 血管形成の遅延に伴い酸素供給の低下した領域, “低酸素領域”が形成されることが知られている. ${ }^{11}$ 低酸素領域は腫瘍の悪性化, 薬物及び放射線治療に 対する抵抗性に関与することから，腫瘍内における 本領域部位の存在及び局在を同定することは，腫瘍 の悪性度鑑別及び放射線治療部位の決定・効果予測 等の指標として有効であると考えられている. ${ }^{2)}$ が し組織内の低酸素領域を同定する手法として，特定 の分子の分布を非侵襲的に体外から可視化できる分

京都大学医学部附属病院放射線部（广606-8507 京都市 左京区聖護院川原町 54)

e-mail: yoichis@kuhp.kyoto-u.ac.jp

本総説は, 平成 29 年度日本薬学会近畿支部奨励賞（医

療系薬学）の受賞を記念して記述したものである.
子イメージング技術，特に放射性同位元素 $\left(\beta^{+}\right.$線 放出核種， $\gamma$ 線放出核種）を標識した薬剂を用いた in vivo 分子イメージング手法である陽電子放射断 層撮像法 (positron emission tomography; PET) や 単一光子放射断層撮影 (single photon emission computed tomography; SPECT) などの核医学イ メージング法が注目されている. ${ }^{3)}$ 核医学イメージ ング法による低酸素領域の同定には主に 2-nitroimidazole を母体骨格に有する F-18 ( $\beta^{+}$線放出核 種）標識イメージング剂が用いられており，中でも $\left[{ }^{18} \mathrm{~F}\right]$ fluoromisonidazole $\left(\left[{ }^{18} \mathrm{~F}\right] \mathrm{FMISO}\right)$ は現在様々 な研究に用いられており, 臨床応用が進んでいる (Fig. 1) .3) 2-Nitroimidazole を母体骨格に有するイ メージング剂は細胞内に受動拡散等により移行した 後, 細胞内のニトロレダクターゼ等により 2-nitroimidazole 環のニトロ基が還元されることが知られ 
A<smiles>O=[N+]([O-])c1nccn1CC(O)C[18F]</smiles>

B

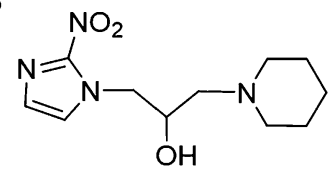

Fig. 1. Chemical Structures of 2-Nitroimidazole Based Compounds

A: $\left[{ }^{18} \mathrm{~F}\right]$ FMISO, B: pimonidazole.

ている，通常酸素環境下においては，細胞内に存在 する酸素により再酸化され, 元の化学形態に戻り, 再び細胞外に排泄されるが，低酸素環境下ではこの 再酸化反応が抑制されることにより還元反応がさら に進行し，最終的に生体内高分子と共有結合するこ とにより，細胞内に滞留し，低酸素領域を描出して

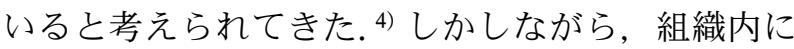
おける放射能分布評価に用いられているオートラジ オグラフィー（autoradiography; ARG）法や PET イメージング法など放射性同位元素を用いた従来の 分析手法では，投与された放射性同位元素に由来す る放射能の空間的分布を評価する手法であるため, 得られた画像から化合物の化学形態を区別すること は極めて困難であった，そのため，実際にどのよう な $\left[{ }^{18} \mathrm{~F}\right]$ FMISO 代謝物が低酸素領域の描出に関与 しているかについて評価することは極めて難しく， その詳細な集積メカニズムは明らかとされていな かった.

ところで，質量分析法は分子の質量を分析する手 法であり，フーリエ変換イオンサイクロトロン共鳴 質量分析装置 (Fourier transform ion cyclotron resonance mass spectrometry; FTICR-MS）など高質 量分解能で分析可能な質量分析装置を用いて薬剤の 代謝物などを同定する研究が盛んに行われてい る. ${ }^{5)} さ ら に$ 近年, この質量分析法に基づく新たな 分子イメージング手法として質量分析イメージング 法 (imaging mass spectrometry; IMS) が開発され てきた. ${ }^{6}$ IMS は組織切片上における分子の分布を 質量情報に基づき直接可視化できることから，脂質 などの内因性生体分子や薬物や薬物代謝物など様々 な分子の分布評価に用いられている. ${ }^{7,8)}$ IMS は, 薬物代謝領域で従来用いられてきている放射性同位 元素を用いた分析手法とは異なり，測定対象分子に 特異的な分子プローブを必要とせず，一度の測定で 複数の分子の分布を同時に評価することが可能であ り，薬物及びその代謝物の分布をそれぞれ選択的に

可視化することができる. ${ }^{9)}$

本稿では，質量分析，特に IMS 技術と放射性同 位元素を用いる核医学イメージング手法とを融合す ることにより，腫瘍内低酸素領域における 2-nitroimidazole を母体骨格に有する低酸素イメージング 剤（FMISO 及び pimonidazole）の化学形態及びそ の分布を評価し，本イメージング剂の低酸素領域へ の集積メカニズムの解明を試みた研究成果について 紹介する.

2. PET 診断用低酸素イメージング剂 “FMISO”, の低酸素環境下組織内における代謝物評価 ${ }^{10)}$

まず, 固形腫瘍低酸素領域に集積した $\left[{ }^{18} \mathrm{~F}\right] \mathrm{FMISO}$ の化学形態を評価するため, ${ }^{18}$ F $]$ FMISO（270-430 $\mathrm{MBq}, 550 \mathrm{mg} / \mathrm{kg}$ ) を投与した $\mathrm{FaDu}$ ヒト頭頸部が し細胞移植 Balb/c ヌードマウスの腫瘍組織を投与 4 時間後に摘出し，腫瘍ホモジネートを作製した 後, メタノール抽出法により生体内高分子への共有 結合割合を評価した。その結果，腫瘍組織における 高分子画分の放射能存在割合は $32.2 \pm 4.0 \%$ であ り，従来の想定とは異なり, ${ }^{4)}$ 投与した FMISO の 過半数が低分子画分に存在することを見い出した. そこで抽出した腫瘍ホモジネート低分子画分につい て，ラジオ高速液体クロマトグラフィー（radioHPLC）法により $\left[{ }^{18} \mathrm{~F}\right]$ FMISO 由来成分を分析した ところ，FMISO 及び 2-nitroimidazole 骨格のニト ロ基がアミノ基に還元された FMISO 代謝物 (amino-FMISO) をそれぞれ存在比約 20\%，約 5\% で検出したことに加え，未知の化学形態を有する画 分を存在比約 $45 \%$ で検出した。このことより,

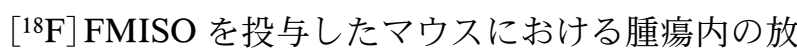
射能分布像はこの未知の化学形態を有する画分の分 布を強く反映している可能性が示唆された.

そこで，FMISO 及び amino-FMISO の分布を評 価するため, FMISO 投与マウス腫瘍組織凍結切片 について，超高質量分解能を有する FTICR-MS を 用いた IMS 測定を行った。その結果, FMISO $(m / z: 190 \rightarrow m / z: 174.067)$ 及び amino-FMISO $(m / z: 160.088)$ は腫瘍内にて均一な分布を示し, その分布は ARG 法により同定した放射能分布及び pimonidazole（外因性低酸素マーカー）免疫組織染 色の陽性領域とは一致しなかった [Figs. 2(A)， (B), (F) and (G)]. また, FMISO から aminoFMISO に還元代謝される際の中間代謝物と推測さ 

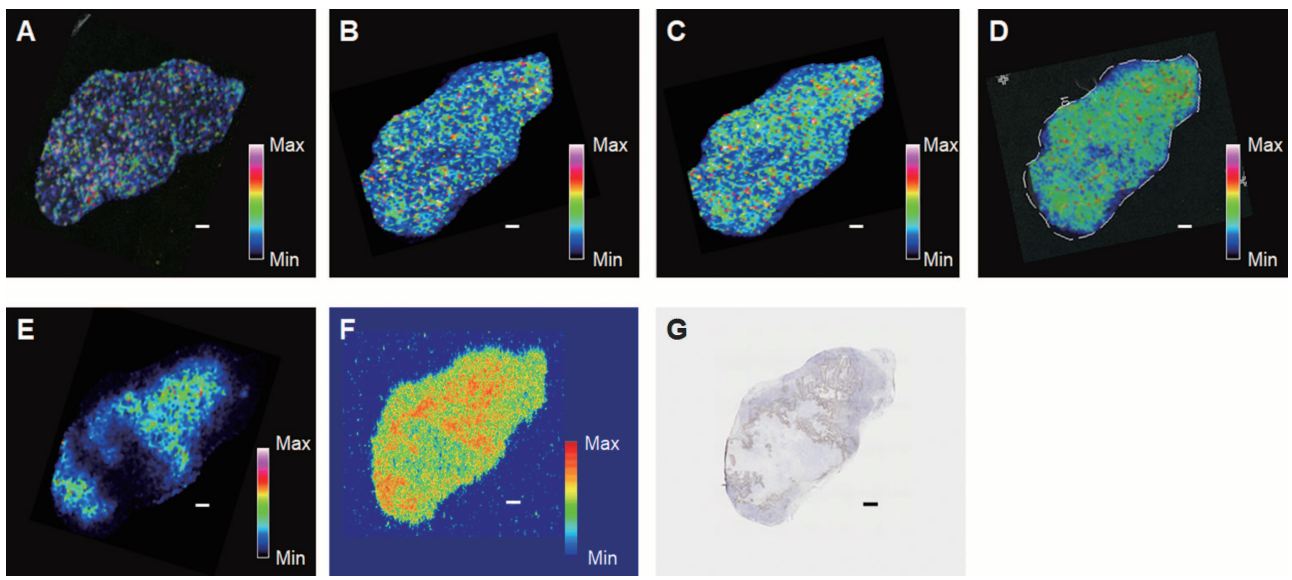

G

Fig. 2. Representative Mass Spectrometric Images of FMISO and Its Metabolites, ARG and Pimonidazole Staining in Mouse Tumors at $4 \mathrm{~h}$ after Administration of FMISO

(A): IMS images of FMISO $(m / z: 190 \rightarrow m / z: 174.067)$. (B): IMS images of amino-FMISO $(m / z: 160.088)$. (C): IMS images of nitroso-FMISO ( $m / z$ : 174.067). (D): IMS images of hydroxylamino-FMISO $(\mathrm{m} / z: 176.083)$. (E): IMS images of amino-FMISO-GS $(\mathrm{m} / \mathrm{z}: 465.157)$. (F): ARG image derived from fluorine-18. (G): Immunohistochemical staining of pimonidazole. The scale bar represents $1 \mathrm{~mm}$. Reproduced with some modifications from Ref. 10) with permission from publisher.

れる分子 (nitroso-FMISO; $m / z: 174.067$, hydroxylamino-FMISO; $m / z:$ 176.083) も腫瘍組織内に存在 することを認めたが，これら中間代謝物の分布も FMISO と amino-FMISO と同様に腫瘍内にて均一 であり，ARG 及び pimonidazole 免疫組織染色とは 一致しなかった [Figs. 2(C) and (D)]。そこで，低 酸素領域には未知の FMISO 代謝物が分布している と考え，FMISO 投与による腫瘍内低分子の変動分 子を IMS 測定により探索したところ，ARG 及び pimonidazole 免疫組織染色の陽性領域と類似した 分布を示す未知分子 $(m / z: 465.157)$ を見い出した [Fig. 2(E) ]. そこで，この未知分子の化学形態を 推定するため, 超高質量分解能測定による組成解析 を行ったところ，本未知分子の精密質量及び同位体 パターンは組成式が $\mathrm{C}_{16} \mathrm{H}_{26} \mathrm{FN}_{6} \mathrm{O}_{7} \mathrm{~S}$ である化合物と 一致し，このような組成式を持つ FMISO 代謝物と して amino-FMISO のグルタチオン抱合体（aminoFMISO-GS）が推定された. 次に，腫瘍中における amino-FMISO-GS の生成を確認するため, FMISO 投与マウス腫瘍ホモジネートについて，液体クロマ トグラフィータンデム質量分析 (LC-MS/MS 分析) による構造解析を行ったところ，amino-FMISOGS の標準物質と一致するプロダクトイオンを複数 検出したことから，腫瘍中に存在する FMISO 未知 代謝物は推定通り amino-FMISO-GS であることを 確認した。ささらに radio-HPLCにより低分子画分 における amino-FMISO-GS 存在割合を再評価した
ところ, FMISO の存在比率は約 20\%と低かったの に対し, amino-FMISO-GS の存在比率は約 50\%で あり, 腫瘍組織中において FMISO は主に aminoFMISO-GS として存在することが示された.

グルタチオンはグルタミン酸，システイン，グリ シンからなるトリペプチドであり，特に還元型グル タチオン（glutathione-SH; GSH）は細胞内に流入 した低分子化合物と結合してグルタチオン抱合体を 形成し，化合物の極性を上げる能力を有することが

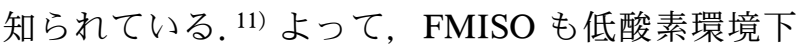
の細胞内にてグルタチオン抱合体を形成することに よりその極性が上昇し，その結果細胞内に滞留して いるものと推測された.

以上の結果より， $\left.{ }^{18} \mathrm{~F}\right] \mathrm{FMISO} の$ 腫瘍組織内低酸 素領域への集積には，従来想定されていた生体内高 分子への共有結合に加え, FMISO 還元代謝物のグ ルタチオン抱合体（amino-FMISO-GS）が大きく 寄与していることを見い出した.

3. イメージング質量分析による免疫組織染色用 低酸素マーカー “Pimonidazole” の腫瘍内集積メカ ニズムの解明 ${ }^{12}$

2.の検討において, FMISO は低酸素環境下の細 胞内にて還元代謝を受けた後，グルタチオン抱合反 応を受けることにより細胞内に集積していることを 明らかにした。そこで，この集積メカニズムが FMISO 特有のものであるか，あるいは他の 2nitroimidazole を母体骨格に有する化合物でも同様 

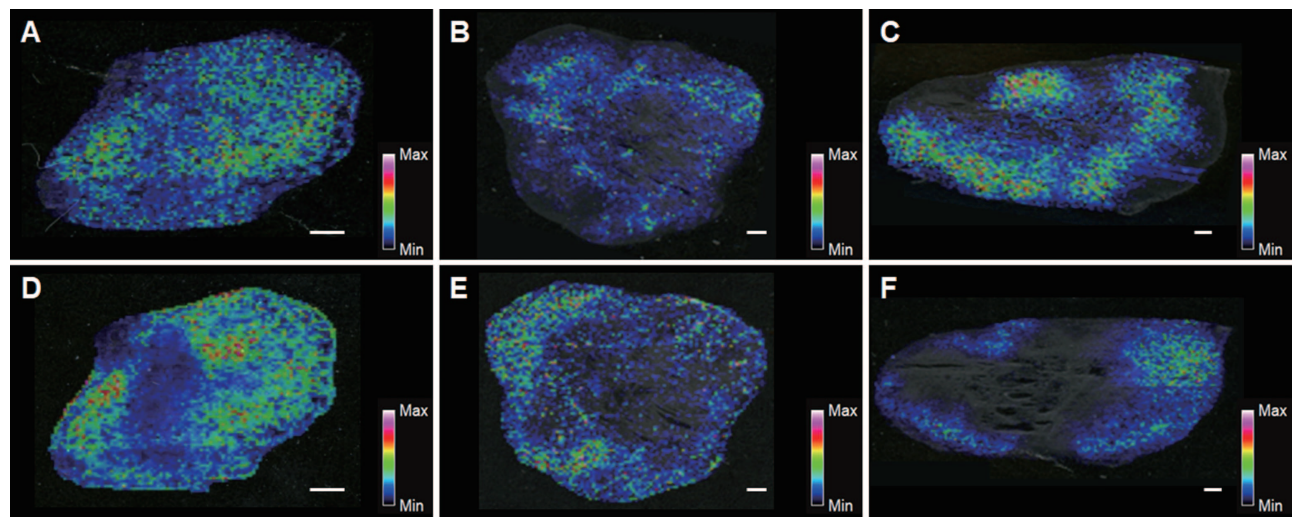

Fig. 3. Representative Mass Spectrometric Images of Amino-pimonidazole and Reduced Glutathione (GSH) in Mouse Tumors

(A) -(C): IMS images of amino-pimonidazole-GS $(\mathrm{m} / \mathrm{z}: 530.239)$. (D)-(F): IMS images of GSH $(\mathrm{m} / \mathrm{z}: 308.091)$. (A), (D): IMS images at $0.5 \mathrm{~h}$ after administration of pimonidazole. (B), (E): IMS images at $2 \mathrm{~h}$ after administration of pimonidazole. (C), (F) : IMS images at $4 \mathrm{~h}$ after administration of pimonidazole. The scale bar represents $1 \mathrm{~mm}$. Reproduced with some modifications from Ref. 12) with permission from publisher.

の集積メカニズムで低酸素領域に集積するのかにつ いて検証するため, FMISO と同様に2-nitroimidazole を母体骨格に有し，免疫組織染色による低酸 素領域の同定に広く用いられている低酸素マーカー “pimonidazole”について，腫瘍組織内における代 謝物評価を行つた。

まず， pimonidazole 及びその代謝物の腫瘍組織 内分布を評価するため, FMISO の検討の際と同様 に, $\mathrm{FaDu}$ 移植マウスに pimonidazole $(200 \mathrm{mg} / \mathrm{kg})$ を投与し，投与 $0.5,2,4$ 時間後に腫瘍を摘出して 薄切凍結切片を作製した。得られた凍結切片につい て IMS 測定を行つたところ，いずれの凍結切片か らも pimonidazole $(m / z: 255.145)$, pimonidazole 還 元体 (amino-pimonidazole, $m / z: 225.171$ ), aminopimonidazole のグルタチオン抱合体（amino-pimonidazole-GS, $m / z: 530.239)$, 及び pimonidazole 還 元中間体 (nitroso-pimonidazole, $m / z: 239.150$, hydroxylamino-pimonidazole, $m / z: 241.166)$ と一致 する $m / z$ を検出した。 なお, amino-pimonidazoleGS については pimonidazole 投与マウス腫瘍ホモジ ネートサンプルの LC-MS/MS 分析により，別途合 成した標品と同位体パターン及びフラグメントイオ ンが一致することを確認した。また, pimonidazole, amino-pimonidazole, nitroso-pimonidazole, hydroxylamino-pimonidazole は投与 4 時間後まで FMISO を用いた検討の際と同様に腫瘍組織内にお いて均一に分布しており, pimonidazole の免疫組 織染色陽性領域とは一致しなかった。一方, amino-pimonidazole-GS は投与 0.5 時間後より腫瘍
組織内で不均一な分布を示し, pimonidazole の免 疫組織染色陽性領域と一致することを認めた。この ことより, pimonidazole は投与早期より腫瘍組織 の低酸素領域内において還元代謝及びグルタチオン 抱合反応を受けて集積していることが示唆された.

2. でも述べたように，グルタチオン抱合反応に はグルタチオン（特に還元型グルタチオン；GSH） が関与していることから, 次に, 腫瘍組織内におけ る amino-pimonidazole-GS と GSH の分布について, IMS を用いて経時的に観察した。 その結果，投与 0.5 時間後では amino-pimonidazole-GS の分布と GSH の分布との間に明瞭な相関は認められなかつ たのに対し，投与 4 時間後では GSH は aminopimonidazole-GS の分布が確認された領域では検出 されなかった（Fig. 3).2-Nitroimidazole 構造を有 する化合物を細胞に添加すると細胞内 GSH が減少 するという現象が報告されており, ${ }^{13)}$ 今回 IMS 測 定にて観察された amino-pimonidazole-GS が分布 する腫瘍内領域から GSH が経時的に消失した現象 は, pimonidazole が腫瘍内に移行した後, 組織内 の GSH を消費してグルタチオン抱合体を形成する ことを示しているものと考えられる.

ところで, pimonidazole の免疫組織染色作業に は極性溶媒を用いた洗浄工程が含まれていることか ら, 免疫組織染色時と同様に洗浄した後, IMS 測 定を行つた。 その結果，洗浄を行っていない腫瘍組 織切片では検出された amino-pimonidazole-GS 由 来のイオン強度が洗浄を行つた腫瘍組織切片上では 著しく低下したことから, pimonidazole の免疫組 
織染色では amino-pimonidazole-GS ではなく，別 の pimonidazole 由来代謝物を認識して染色してい ることが示唆された。同様に， $\left[{ }^{18} \mathrm{~F}\right] \mathrm{FMISO}$ を投与 したマウス腫瘍組織切片について, 洗浄した後に ARG 測定を行ったところ，洗浄をしていない組織 切片と比べて洗浄後の組織切片では放射能分布の領 域は同じであるもののその集積量が低下しているこ とを認めた．2.の検討において， $\left.{ }^{18} \mathrm{~F}\right] \mathrm{FMISO}$ は腫 瘍内において高分子画分にも一部存在していたこと を考慮すると, pimonidazole の免疫組織染色では pimonidazole の生体内高分子との共有結合体のみ を描出していると考えられる。 また，冒頭でも記載 したように IMS は一度の測定で複数の分子を同時 に画像化することが可能であり，かつ免疫組織染色 とは異なり，観察対象の抗原に対する特異的抗体が 不要である.よって，IMS により同定した aminopimonidazole-GS の分布と pimonidazole 免疫組織 染色の陽性領域がほぼ同等であったことを考慮する と, IMS による amino-pimonidazole-GS の分布を 評価することにより組織内低酸素領域をより簡便に 同定できる可能性が示唆された.

以上の結果より，FMISO で観察された腫瘍組織 内低酸素領域への集積メカニズム（還元代謝後，グ ルタチオン抱合体を形成）は FMISO のみならず, 2-nitroimidazole を母体骨格に有する化合物におい て認められる普遍的な現象である可能性が示された.

\section{FMISO の低酸素環境下細胞への集積と細胞} 内グルタチオン抱合因子発現・活性度との関連性評 価14)

FMISO や pimonidazole など 2-nitroimidazole を 母体骨格に有する低酸素イメージング剂は，腫瘍組 織内で還元代謝を受けた後，グルタチオン抱合体を 形成することで低酸素領域に集積していることを明 らかとした．ところで，グルタチオン抱合反応は, 反応を触媒する酵素の活性や細胞腫等により影響を 受けることが知られている. ${ }^{15)}$ また FMISO は酸素 濃度が一定の条件下においても細胞の種類によりそ の集積量が異なることが報告されている.16) そこ で，がん細胞の種類と FMISO 集積量，グルタチオ ン抱合体生成量及びグルタチオン抱合体形成能との 関連性について評価した。

まず， 3 種類のがん細胞（FaDu 細胞， LOVO ヒ 卜結腸がん細胞， T24 ヒト膀胱がん細胞）に $\left.{ }^{18} \mathrm{~F}\right]$
FMISO (2.5 MBq, $250 \mathrm{nmol} /$ well) を添加し，通常 酸素環境下あるいは低酸素環境下（酸素濃度：1\%) で 4 時間インキュベートした，その結果，通常酸素 条件下の各細胞における放射能の集積量はいずれの 細胞種とも低く，ほぼ同等であった（FaDu；0.122 \pm 0.009 , LOVO; $0.223 \pm 0.048$, T24; $0.100 \pm 0.005 \%$ dose/mg protein)。一方，低酸素環境下の細胞にお ける放射能集積量は，FaDu 細胞において最も高く $(0.851 \pm 0.009 \%$ dose $/ \mathrm{mg}$ protein $), \mathrm{LOVO}$ 細胞では 中程度の集積がみられたのに対し（0.617 $\pm 0.021 \%$ dose/mg protein)，T24 細胞における集積量は有意 に低くなった $(0.167 \pm 0.011 \%$ dose $/ \mathrm{mg}$ protein, $p<0.01)$. FMISO の生体内高分子への共有結合割 合を，細胞懸濁液のメタノール抽出により算出した ところ, $\mathrm{FaDu}$ 細胞では $29.77 \pm 0.47 \%, \mathrm{LOVO}$ 細胞 では $36.71 \pm 1.28 \%, \mathrm{~T} 24$ 細胞では $47.20 \pm 1.84 \%$ で あった。また，抽出した低分子画分について LCMS/MS 測定を行ったところ， FaDu 細胞，LOVO 細胞及び $\mathrm{T} 24$ 細胞のいずれにおいても細胞内で amino-FMISO-GS が生成していることを確認する とともに，その生成量は放射能集積量と相関するこ とを見い出した（FaDu： $0.502 \pm 0.035 ，$ LOVO: $0.158 \pm 0.006, \quad$ T24: $\quad 0.007 \pm 0.001 \% \quad$ dose $/ \mathrm{mg}$ protein). 以上のことから, FMISO は同一低酸素 環境下においても細胞種によりその集積量が異な り，その集積量の変化には amino-FMISO-GS の生 成度合いが関与している可能性が示された。

そこで，FaDu，LOVO 及び T24 細胞における細 胞内グル夕チオン抱合関連因子の発現量・活性度に ついて評価した。 まず，細胞内 GSH 量について測 定したところ， $\mathrm{FaDu}$ 細胞では評価に用いた 3 つの 細胞種の中で最も高值を示し，LOVO 細胞及び T24 細胞ではほぼ同程度であった（FaDu； 650.5 39.3 , LOVO; $147.7 \pm 7.9$, T24; $214.7 \pm 32.7 \mathrm{nmol} / \mathrm{mg}$ protein)。なお，酸化型グルタチオン（GSSG）に ついても測定したところ，いずれの細胞においても $\mathrm{GSH}$ と比べて極めて低值であり $(\mathrm{FaDu} ; 23.9 \pm 1.3$, LOVO; $1.7 \pm 0.1, \mathrm{~T} 24 ; 1.8 \pm 0.2 \mathrm{nmol} / \mathrm{mg}$ protein), 細胞内グルタチオンの大半は 2-nitroimidazole との 反応性に富む還元型（GSH）として存在し，特に FMISO 高集積細胞（今回の検討では FaDu 細胞） 内に豊富に存在することが示された。また，グル夕 チオン抱合反応はグルタチオン抱合酵素 


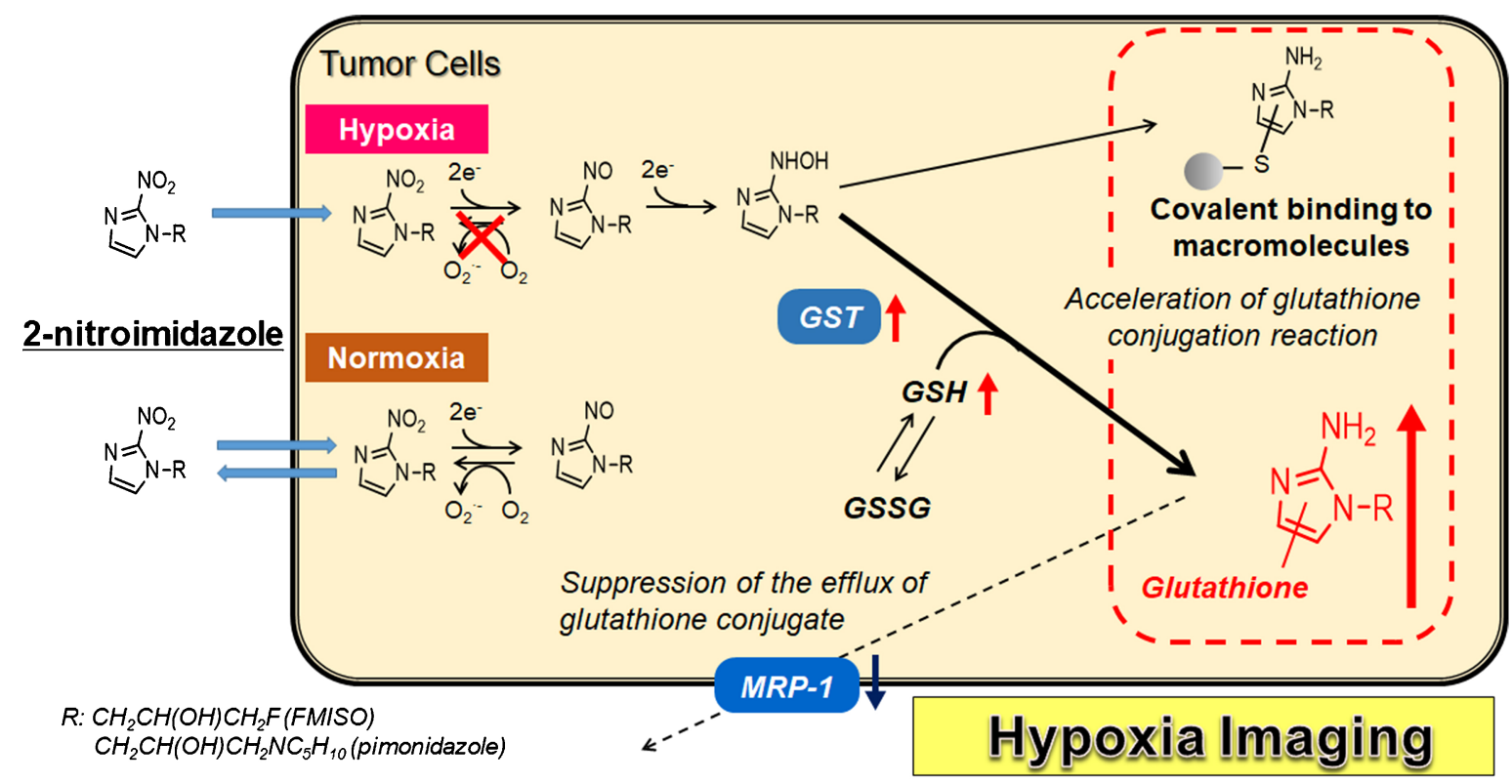

Fig. 4. Proposed Mechanism of the Reduction and Accumulation of 2-Nitroimidazole Based Imaging Probes in Hypoxic Cells Revealed from This Study

(Color figure can be accessed in the online version.)

（glutathione $S$-transferase; GST）の触媒反応によ り GSH のチオール基が求電子性化合物と求核反応 することにより進行することが知られている，そこ で，各細胞における GST の酵素活性について測定 したところ， FaDu 細胞及び LOVO 細胞における GST 活性は T24 細胞と比較して有意に高かった (FaDu; 10.56 \pm 0.87 , LOVO; 11.82 \pm 0.83 , T24; 5.13 $\pm 1.04 \Delta \mathrm{OD}_{340} / \mathrm{min} / \mathrm{mg}$ protein). ところで, GST には複数のアイソザイムが存在し，中でも GST $\pi$ は様々ながん細胞において豊富に存在することが知 られている. ${ }^{17)}$ そこで，GST $\pi$ の遺伝子である GSTP1の mRNA 発現量についてリアルタイム PCR により評価したところ，その発現量は FaDu 細胞において LOVO 細胞及び $\mathrm{T} 24$ 細胞と比較して 有意に高かった（GSTP1/ $\beta$-actin 比：FaDu；0.66士 0.05 , LOVO; 0.07 \pm 0.01 , T24; 0.02 \pm 0.01$)$ 。これら の結果より, FMISO 高集積細胞（FaDu 細胞）で は細胞内 GSH 存在量に加え, GST の発現量, 酵素 活性が高いことにより，FMISO のグルタチオン抱 合反応が克進し，低酸素環境下における放射能集積 量が増加したものと考えられる。一方，細胞膜には ATP 依存的に様々なグルタチオン抱合体を細胞外 に排出する ATP 結合カセットトランスポーター ファミリー，多剤耐性関連タンパク質 (multidrug resistance-associated protein; MRP) が発現してお
り，中でも MRP1 は広い基質特異性を有するグル タチオン抱合体トランスポーターとして知られてい る. ${ }^{18)}$ そこで， MRP1の mRNA 発現量をリアル夕 イム PCR により評価したところ，その発現量は放 射能集積量と反比例の関係を示した (MRP1/ $\beta$-actin 比 : FaDu; $0.15 \pm 0.01, \mathrm{LOVO} ; 0.25 \pm 0.04, \mathrm{~T} 24 ; 0.43 \pm$ 0.04）。このことは，FMISO 低集積細胞（今回の検 討では T24 細胞) では MRP1 が高発現することに より amino-FMISO-GS の細胞外排出が促進され, その結果 FMISO 由来の細胞内放射能集積量が低下 したと理解できる.

以上の結果より， $\left.{ }^{18} \mathrm{~F}\right] \mathrm{FMISO}$ の細胞内集積には 低酸素状態に加えて amino-FMISO-GS の生成立 進, 排出低下の度合いが重要であることが示され, $\left[{ }^{18} \mathrm{~F}\right] \mathrm{FMISO}$ を用いた PET 診断により得られる画 像は低酸素領域のみならず，グルタチオン抱合関連 因子の発現・活性度を反映している可能性が示唆さ れた.

\section{5. おわりに}

以上の検討より，2-nitroimidazole を母体骨格に 有するイメージング剂は腫瘍組織内の低酸素環境下 細胞内において，還元代謝を受けた後，主にグル夕 チオン抱合体として滞留していることを明らかにし た。また，その集積には低酸素環境であることに加 えて, グルタチオン抱合関連因子の発現度・活性度 
が関与していることを明らかにした（Fig. 4).

本来，グルタチオン抱合関連因子については，細 胞内の発現度の違いに加え，投与された薬剤の酵 素・トランスポーター活性度への影響も考慮する必 要があり，例えばシスプラチンなどの抗がん剂治療 を受けている患者では腫瘍内 GSH 枯渇が報告され

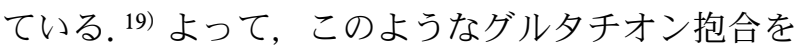
受ける薬物を投与された患者では，同様に細胞内 GSH を消費する $\left[{ }^{18} \mathrm{~F}\right]$ FMISO は腫瘍組織内におい て競合阻害を受ける可能性が想定される。これらの 知見は， $\left[{ }^{18} \mathrm{~F}\right]$ FMISO を用いた核医学診断におい て，腫瘍の種類や治療歴等の患者状態が診断精度に 影響を与える可能性を示している.

現在も新たな低酸素イメージング剂の開発研究が 盛んに進められているが，その中で筆者も今回行つ た IMS と核医学イメージング手法を融合した評価 法を用いることにより，新規に開発した低酸素イ メージングの集積メカニズムを明らかにすることに 成功している. ${ }^{20)}$ ほかにも標的組織内で代謝される ことにより特異的に集積するイメージング剂が数多 く報告されていることから，今後このような代謝捕 捉型イメージング剂の開発研究において，従来の手 法に IMS の技術を組み合わせることにより，より 精密な集積メカニズム解明・ドラッグデザインが可 能となり，核医学イメージング剂は勿論，一般治療 薬の創薬研究に貢献することが期待される.

\section{謝辞本研究の遂行に際しまして, 終始に渡り} ご指導とご鞭撻を賜りました北海道大学アイソトー プ総合センター久下裕司教授に謹んで感謝申し上 げます。また，本研究の遂行にあたり多大なる貢献 を頂きました塩野義製薬株式会社 正木悠紀子博士 を始め北海道大学アイソトープ総合センター, 北海 道大学大学院医学研究院核医学教室の先生方, 塩野 義製薬株式会社の共同研究者の皆様に感謝申し上げ ます。最後に，学生時代より終始懇篤なご指導とご 鞭撻を賜り，この度日本薬学会近畿支部奨励賞にご 推薦頂いた京都大学大学院薬学研究科 佐治英郎名 誉教授に感謝申し上げます.

利益相反＼cjkstart開示すべき利益相反はない.

\section{REFERENCES}

1) Wilson W. R., Hay M. P., Nat. Rev. Cancer, 11, 393-410 (2011).

2) Horsman M. R., Mortensen L. S., Petersen J. B., Busk M., Overgaard J., Nat. Rev. Clin. Oncol., 9, 674-687 (2012).

3) Troost E. G., Laverman P., Philippens M. E., Lok J., van der Kogel A. J., Oyen W. J., Boerman O. C., Kaanders J. H., Bussink J., Eur. J. Nucl. Med. Mol. Imaging, 35, 18031811 (2008).

4) Krohn K. A., Link J. M., Mason R. P., J. Nucl. Med., 49 (Suppl. 2), 129S-148S (2008).

5) Patti G. J., Yanes O., Siuzdak G., Nat. Rev. Mol. Cell Biol., 13, 263-269 (2012).

6) Caprioli R. M., Farmer T. B., Gile J., Anal. Chem., 69, 4751-4760 (1997).

7) Gobey J., Cole M., Janiszewski J., Covey T., Chau T., Kovarik P., Corr J., Anal. Chem., 77, 5643-5654 (2005).

8) Sugimoto M., Shimizu Y., Yoshioka T., Wakabayashi M., Tanaka Y., Higashino K., Numata Y., Sakai S., Kihara A., Igarashi Y., Kuge Y., Biochim. Biophys. Acta, 1851, 15541565 (2015).

9) Castellino S., Groseclose M. R., Wagner D., Bioanalysis, 3, 2427-2441 (2011).

10) Masaki Y., Shimizu Y., Yoshioka T., Tanaka Y., Nishijima K., Zhao S., Higashino K., Sakamoto S., Numata Y., Yamaguchi Y., Tamaki N., Kuge Y., Sci. Rep., 5, 16802 (2015).

11) Hayes J. D., Flanagan J. U., Jowsey I. R., Annu. Rev. Pharmacol. Toxicol., 45, 51-88 (2005).

12) Masaki Y., Shimizu Y., Yoshioka T., Feng F., Zhao S., Higashino K., Numata Y., Kuge Y., PLoS One, 11, e0161639 (2016).

13) Bérubé L. R., Farah S., McClelland R. A., Rauth A. M., Int. J. Radiat. Oncol. Biol. Phys., 22, 817-820 (1992).

14) Masaki Y., Shimizu Y., Yoshioka T., Nishijima K. I., Zhao S., Higashino K., Numata Y., Tamaki N., Kuge Y., Ann. Nucl. Med., 31, 596-604 (2017).

15) Townsend D. M., Tew K. D., Oncogene, 22, 7369-7375 (2003). 
16) Rasey J. S., Nelson N, J., Chin L., Evans M. L., Grunbaum Z., Radiat. Res., 122, 301-308 (1990).

17) Yellin S. A., Davidson B. J., Pinto J. T., Sacks P. G., Qiao C., Schantz S. P., Cancer Lett., 85, 223-232 (1994).

18) Ishikawa T., Kuo M. T., Furuta K., Suzuki
M., Cytotechnology, 27, 81-93 (1998) .

19) Komiya S., Gebhardt M. C., Mangham D. C., Inoue A., J. Orthop. Res., 16, 15-22 (1998).

20) Shimizu Y., Zhao S., Yasui H., Nishijima K. I., Matsumoto H., Shiga T., Tamaki N., Ogawa M., Kuge Y., Mol. Imaging Biol., in press. doi: 10.1007/s11307-018-1214-y 